\title{
Identification of Protein Phosphatase 1 in Synaptic Junctions: Dephosphorylaton of Endogenous Calmodulin-dependent Kinase II and Synapse-enriched Phosphoproteins ${ }^{1}$
}

\author{
STEVEN M. SHIELDS, THOMAS S. INGEBRITSEN, ${ }^{\star}$ AND PAUL T. KELLY² \\ Department of Neurobiology and Anatomy, University of Texas Health Science Center, The Medical School, Houston, Texas 77225, and \\ ${ }^{\star}$ Department of Pharmacology, University of Colorado Health Science Center, Denver, Colorado 80262
}

\begin{abstract}
A calcium/calmodulin-dependent protein kinase termed CaM-kinase II is a major component of synaptic junctions from forebrain and constitutes approximately $12 \%$ of total synaptic junction protein. CaM-kinase II phosphorylates at least seven polypeptides that are enriched in synaptic junctions, of which two represent the 50- and 60-kilodalton subunits of the protein kinase. In this report the nature of endogenous protein phosphatases which dephosphorylate each of the seven synaptic junction phosphoproteins was examined. Assays of synaptic junctions and other subcellular fractions from rat forebrain for type- 1 and type-2 protein phosphatases revealed that protein phosphatase $1(\mathrm{PrP}-1)$ was specifically enriched in synaptic junctions with respect to cytosolic fractions. The activity of type-2 protein phosphatases was very low in synaptic junctions. Homogeneous PrP-1 from rabbit skeletal muscle was found to dephosphorylate each of the seven phosphoproteins in synaptic junctions. Inhibitors-1 and -2 were found to inhibit endogenous protein phosphatase activity by 70 to $80 \%$. Since inhibitors -1 and -2 are specific inhibitors of PrP-1, these results indicate that this enzyme accounts for the majority of endogenous protein phosphatase activity in synaptic junctions. Approximately $15 \%$ of the protein phosphatase activity in synaptic junctions was type $2 A$, whereas PrP-2B and PrP-2C accounted for little, if any, of the activity toward endogenous or exogenous phosphoproteins. These results indicate that PrP-1 may be important in controlling the state of phosphorylation of synaptic junction proteins.
\end{abstract}

Several protein kinases have been studied in neural tissues that require calcium and calmodulin $\left(\mathrm{CaM}^{3}\right)$ for activity (Kennedy and

Received March 22, 1985; Revised May 13, 1985;

Accepted May 13, 1985

\footnotetext{
${ }^{1}$ We thank Steve Whetzel and Jim McCarthy for their technical assistance and Henry Tomasiewicz for carrying out protein phosphatase- $2 \mathrm{~B}$ and $-2 \mathrm{C}$ assays. This work was supported by National Institutes of Health Grant NS15554 and National Science Foundation Grant BNS 81-06259, by a Career Development Award and Sloan Research Fellowship to P. T. K., and by National Institutes of Health Grant NS 09199 to T. S. I. T. S. I. is an Established Investigator of the American Heart Association.

${ }^{2}$ To whom correspondence should be addressed

${ }^{3}$ The abbreviations used are: CaM, calmodulin; CaM-kinase ॥, $\mathrm{Ca}^{2+} /$ calmodullin-dependent protein kinase II; DTT, dithiothreitol; $\mathrm{kd}$, kilodalton; MPSDp, major postsynaptic density protein; PMSF, phenylmethylsulfonyl fluoride; PrP, protein phosphatase; PSD, postsynaptic density; SJ, synaptic junction; SPM, synaptic plasma membrane; TCA, trichloroacetic acid; TX, Triton X-100; TX-sol SPM, Triton-soluble synaptic plasma membrane.
}

Greengard, 1981; Goldenring et al., 1982; Yamauchi and Fujisawa, 1982, 1983; Kennedy et al., 1983a; Palfrey et al., 1983; Schulman, 1984). A CaM-dependent protein kinase (designated CaM-kinase II) in brain cytosol and particulate fractions that phosphorylates synapsin I (Ueda et al., 1979; De Camilli et al., 1983) has been purified to near homogeneity and is composed of a major 50 -kilodalton $(\mathrm{kd})$ polypeptide and a minor 60-kd polypeptide (Bennett et al., 1983; Groswald et al., 1983; Kennedy et al., 1983a, b; Lai et al., 1983; Kelly et al., 1984). Both polypeptides are phosphorylated in $\mathrm{a} \mathrm{Ca}^{2+} /$ CaM-dependent manner and bind CaM.

CaM-stimulated protein kinase activity is present in postsynaptic densities (PSDs) from canine cerebral cortex (Grab et al., 1981) and has been shown to be concentrated at asymmetric synaptic junctions (Kelly et al., 1983, 1985). At least seven prominent phosphoproleins which serve as in vitro substrates for this CaM-dependent protein kinase are also concentrated in synaptic junctions. Two of these phosphoproteins constitute the 50 - and $60-\mathrm{kd}$ components of CaM-kinase II (Bennett et al., 1983; Kennedy et al., 1983b; McGuinness et al., 1983; Kelly et al., 1984, 1985). The other five include synapsin I and phosphoproteins of 240,207, 170, and $140 \mathrm{kd}$ (Kelly et al., 1985); the putative postsynaptic functions of these phosphoproteins remain unknown.

The most abundant protein in PSDs and synaptic junctions (SJs) is a $50-\mathrm{kd}$ polypeptide which constitutes approximately $50 \%$ of the total protein in isolated PSDs. This polypeptide, designated the major PSD protein (mPSDp), is thought to make up in large part the submembranous cytoskeleton that underlies the postsynaptic membrane at asymmetric synapses (Banker et al., 1974; Kelly and Cotman, 1978; Cotman and Kelly, 1980; Kelly and Montgomery, 1982). Recent work from this laboratory has demonstrated that the major PSD protein is virtually identical to the $50-k d$ polypeptide of CaM-kinase II (Groswald et al., 1983; McGuinness et al., 1983; Kelly et al., 1984). Similarly, a $60-\mathrm{kd}$ phosphoprotein in SJs is highly related to the $60-\mathrm{kd}$ subunit of CaM-kinase II. Some of these molecular similarities have recently been reported by Kennedy et al. (1983b) and Goldenring et al. (1984). The enrichment of CaM-kinase II/ mPSDp at SJs, together with the presence of a number of endogenous substrate proteins, suggests that CaM-dependent protein phosphorylation may play important functional roles at CNS synapses.

The subcellular distribution and properties of protein kinases in brain are consistent with the notion that intracellular signals due to calcium influx into neurons and increases in cyclic nucleotides result in the phosphorylation of specific proteins (Krueger et al., 1977; Forn and Greengard, 1978). In all phosphorylation systems studied to date, the steady-state level of protein phosphorylation is determined by the balance of the protein kinase and protein phosphatase (PrP) activities. Moreover, specific mechanisms have been identified that regulate PrP activity in response to CAMP and calcium (Ingebritsen 
and Cohen, 1983a, b; Huang and Glinsmann, 1976). If .protein phosphorylation is to play important roles in physiological events underlying synaptic communication, one would expect to find PrP activity co-localized with the enzymatic machinery responsible for the phosphorylation of the same substrate proteins. Furthermore, if protein phosphorylation constitutes an activation or "on" event associated with neuronal functions, then for reversible function a given phosphoprotein must be dephosphorylated.

Four enzymes, termed protein phosphatases 1, 2A, 2B, and 2C, account for virtually all of the observed protein phosphatase activity toward a large number of phosphoproteins involved in the regulation of intermediary metabolism (Ingebritsen and Cohen, 1983a, b; Ingebritsen et al., 1983a, b, c; Pato et al., 1983; Stewart et al., 1983). These four PrPs have been divided into two classes (Ingebritsen and Cohen, 1983a, b). Type-1 protein phosphatase (protein phosphatase 1 or PrP-1) selectively dephosphorylates the $\beta$-subunit of phosphorylase kinase and is potently inhibited by nanomolar concentrations of two heat-stable regulatory proteins, termed inhibitors1 and -2 . Conversely, the three type- 2 protein phosphatases (PrP$2 \mathrm{~A},-2 \mathrm{~B}$, and $-2 \mathrm{C}$ ) selectively dephosphorylate the $\alpha$-subunit of phosphorylase kinase and are refractory to inhibitors-1 and -2 . Interestingly, inhibitor- 1 is an active inhibitor of $\mathrm{PrP}-1$ only after being phosphorylated on a specific threonine residue by cAMP-dependent protein kinase (Huang and Glinsmann, 1976)

PrP-1, $-2 \mathrm{~A}$, and $-2 \mathrm{C}$ are active toward a wide range of phosphoprotein substrates, whereas PrP- $2 \mathrm{~B}$ has a very restricted substrate specificity (Ingebritsen and Cohen, 1983b). PrP-2B is a Ca ${ }^{2+}$-dependent enzyme whose activity is stimulated 10-fold by CaM (Stewart et al., 1982, 1983). PrP-2B is identical to a prominent CaM-binding protein in brain cytosol, termed calcineurin (Klee et al., 1979; Stewart et al., 1982; Tonks and Cohen, 1983). PrP-2C is an $\mathrm{Mg}^{2+}$-dependent enzyme, whereas PrP.1 and $-2 \mathrm{~A}$ are active in the absence of divalent cations (Ingebritsen and Cohen, 1983a).

The results presented herein demonstrate that PrP-1 is the major phosphatase activity in SJ and synaptic plasma membrane (SPM) fractions from rat forebrain. PrP-1 accounts for virtually all of the protein phosphatase activity toward the major plosphoproteins present in SJ and SPM fractions that are substrates for CaM-kinase II. Lesser amounts of PrP-2A were observed in SJ and SPM fractions. The possible significance of these findings to the regulation of protein phosphorylation in nerve terminals is discussed.

\section{Materials and Methods}

Subcellular fractionation. SPM and SJ fractions were prepared from rat forebrains (60 to 100 days of age) by the iodonitrotetrazolium violet/Triton $X$ 100 method as previously described (Kelly and Montgomery, 1982); protein concentrations were determined as outlined elsewhere (Kelly and Montgom ery, 1982). SJs were prepared from SPMs by extracting the latter with Triton $X$ - 100 (TX); approximately $85 \%$ of the SPM protein was recovered in detergent extracts. Other subcellular fractions from brain were prepared as previously described (Groswald and Kelly, 1984).

Endogenous phosphorylation of SJ and SPM proteins. Proteins in SJ and SPM fractions were phosphorylated in vitro using $\left[\gamma^{32} \mathrm{P}\right]$ ATP or $\left[\gamma^{-}\right.$ ${ }^{35}$ S)thioadenosine $5^{\prime}$-triphosphate (thioATP) $(5 \mu \mathrm{M}, 6.75 \mu \mathrm{Ci} / 50 \mu$; New England Nuclear) as substrates for endogenous CaM-kinase II as previously described (Kelly et al., 1984) with minor modifications. Phosphorylation reactions were terminated after $1 \mathrm{~min}$ at $30^{\circ} \mathrm{C}$ (ATP) or $30 \mathrm{~min}$ at $24^{\circ} \mathrm{C}$ (thioATP) by the addition of $850 \mu$ l of 2 mM HEPES (pH 7.2), 1 mM EGTA and centrifuging at $10,000 \times g$ for $20 \mathrm{sec}$ or $5 \mathrm{~min}$ for SJ and SPM fractions, respectively. Supernatants were decanted and SJ or SPM pellets were washed two additional times by resuspension and centrifugation in the same buffer. SJ and SPM pellets were resuspended $(1$ to $2 \mu \mathrm{g}$ of protein $/ \mu l)$ in 2 mM HEPES (pH 7.2) and used in dephosphorylation reactions (see below).

Endogenous dephosphorylation of SJ and SPM proteins. ${ }^{32} \mathrm{P}$ - or ${ }^{35} \mathrm{~S}$. labeled SJ or SPM proteins were dephosphorylated at $37^{\circ} \mathrm{C}$ in a standard dephosphorylation buffer that contains $50 \mathrm{~mm}$ Tris- $\mathrm{HCl}, 0.5 \mathrm{~mm}$ dithiothreitol (DTT) (pH 7.0), $25 \mu \mathrm{g} / \mathrm{ml}$ of $\alpha$-2-macroglobulin, $10 \mu \mathrm{g} / \mathrm{ml}$ of leupeptin, 10 $\mu \mathrm{g} / \mathrm{ml}$ of pepstatin $\mathrm{A}$, and $1.5 \mathrm{~mm}$ phenylmethylsulfonyl fluoride (PMSF). Additional dephosphorylation reactions contained $\mathrm{CaCl}_{2}$ and $\mathrm{CaM}(2 \mathrm{mM}$ and $0.02 \mu \mathrm{g} / \mu \mathrm{l}$, respectively), $\mathrm{MgCl}_{2}(2 \mathrm{mM})$, or $\mathrm{EGI} \mathrm{A}(5 \mathrm{~mm})$. In some experiments Triton X-100-soluble SPM fractions (TX-sol SPMs) or purified PrP-1 and/or PrP-2A were added to reactions at $4^{\circ} \mathrm{C}$ prior to initiating protein dephospho- rylation by shifting reactions to $37^{\circ} \mathrm{C}$. In other experiments purified phosphatase inhibitors- 1 and/or -2 were added to reactions. Dephosphorylation reactions were carried out for various durations (10 to $120 \mathrm{~min}$ ) to ensure linearity and were terminated by the addition of $4 \times$ SDS-stop buffer and immediately heated at $70^{\circ} \mathrm{C}$ for $5 \mathrm{~min}$. Reaction mixtures were analyzed on 7 to $16 \%$ exponential gradient slab gels. Gels were stained with Coomassie blue as described previously (Kelly et al., 1979). Autoradiography of gels was performed at $-75^{\circ} \mathrm{C}$ with Curix RP-1 $x$-ray film and Cronex intensifying screens. Autoradiographic patterns were quantitated using a scanning densitometer with intcgrator (E C Apparatus). Multiple autoradiographic expo sures of varying durations were made of each gel to ensure that densitometric measurements were within the linear range of silver grain development. Followiry autoradiographic exposures, ${ }^{32} \mathrm{P}$ - or ${ }^{35} \mathrm{~S}$-labeled bands were excised and subjected to liquid scintillation counting. Results from densitometry and beta counting were in close agreement.

Dephosphorylation of endogenous and exogenous phosphoprotems by synaptic and purified PrPs. Synaptic fractions or purified PrPs were assayed for their ability to dephosphorylate exogenous ${ }^{32} \mathrm{P}$-synapsin I or ${ }^{32} \mathrm{P} \cdot \mathrm{CaM}$ kinase II. Reactions contained $1.0 \mu \mathrm{g}$ of ${ }^{32} \mathrm{P}$-synapsin I or ${ }^{32} \mathrm{P}$-CaM-kinase ॥ and the desired synaptic fraction ( $25 \mu \mathrm{g}$ of protein) or purified $\operatorname{PrP}$ in $45 \mu \mathrm{l}$ of the standard dephosphorylation buffer. Following incubations at $37^{\circ} \mathrm{C}$ or $4^{\circ} \mathrm{C}$, dephosphorylation reactions were terminated and analyzed as described above.

Control reactions using different substrate dilutions and highly purified PrPs of known specific activity were performed to ensure that assays were carried out in the linear range of protein dephosphorylation as a function of time and the amount of added phosphatase. Reactions containing ${ }^{30} \mathrm{P}$ substrates alone, substrates with various buffers, or substrates with heatinactivated subcellular fractions $\left(80^{\circ} \mathrm{C} / 5 \mathrm{~min}\right)$ displayed no detectable $\mathrm{PrP}$ activity.

Alkaline phosphatases from Escherichia coli, human placenta, and bovine intestine, and acid phosphatases from human semen and potato (Sigma Chemical Co.) were assayed for their ability to dephosphorylate purified ${ }^{32} \mathrm{P}$. CaM-kinase \| or ${ }^{32} \mathrm{P}$-SJ phosphoproteins. ${ }^{32} \mathrm{P}$-CaM-kinase $\|(1.8 \mu \mathrm{g})$ was incubated with 0.8 units of each phosphatase using the appropriate alkaline or acid conditions in $45 \mu \mathrm{l}$ of buffer ( $50 \mathrm{~mm}$ Tris- $\mathrm{HCl}, 0.5 \mathrm{~mm}$ DTT) for $90 \mathrm{~min}$ at $4{ }^{\circ} \mathrm{C}$ or $37^{\circ} \mathrm{C}$. Certain reactions contained ${ }^{32} \mathrm{P}$-SJs that were solubilized with SDS $(1 \%)$ prior to the addition of different purified phosphatases. Reactions were terminated as described above and analyzed by autoradiography and liquid scintillation counting.

Assay of ${ }^{32} P$-inorganic phosphate release from phosphoproteins. The release of ${ }^{32} \mathrm{P}$-inorganic phosphate from ${ }^{32} \mathrm{P}$-SJ phosphoproteins was conducted by the phase-separation technique described by Antoniw and Cohen (1976). Briefly, dephosphorylation reactions were terminated with $4 \times$ SDSstop buffer and split into three equal aliquots. One aliquot was analyzed by SDS-PAGE and autoradiography. The remaining duplicates received $50 \mu \mathrm{l}$ of $2 \%$ bovine serum albumin followed by $100 \mu \mathrm{l}$ of ice-cold $17.5 \%(\mathrm{w} / \mathrm{v})$ trichloroacetic acid (TCA). Protein precipitates were allowed to form at $4^{\circ} \mathrm{C}$ for $20 \mathrm{~min}$. Precipitates were collected by centrifugation; supernatants were removed and mixed with $200 \mu \mathrm{l}$ of $1.25 \mathrm{mM} \mathrm{KH}_{2} \mathrm{PO}_{4}$ in $1.0 \mathrm{~N} \mathrm{H}_{2} \mathrm{SO}_{4}$, and 500 $\mu$ l of isobutanol:benzene $(1: 1, v / v)$. Ammonium molybdate $(125 \mu l$ of $5 \%, w /$ v) was added and mixed, and each sample was centrifuged to separate the mixture into organic and aqueous phases. Aliquots $(300 \mu l)$ of the organic phase containing ${ }^{32} \mathrm{P}_{\mathrm{i}}$-molybate complexes were added to liquid scintillation cocktail $(4 \mathrm{ml})$ and counted; ${ }^{32} \mathrm{P}$-peptides which could arise from proteolytic degradation during dephosphorylation reactions are excluded from the organic phase in this assay.

Inactivation of endogenous phosphatases. SJ and SPM fractions ( 1 to 2 $\mu \mathrm{g} / \mu \mathrm{l})$, before or after phosphorylation by endogenous CaM-kinase II, were incubated in $50 \mathrm{~mm} \mathrm{NaF}, 0.5 \mathrm{~mm}$ EDTA at $4^{\circ} \mathrm{C}$ for $30 \mathrm{~min}$ to $2 \mathrm{hr}$. Incubations were terminated by centrifugation $(10,000 \times g$ for $30 \mathrm{sec})$, supernatants were decanted, and pellets were washed three times by resuspension/ centrifugation in $10 \mathrm{~mm}$ HEPES ( $\mathrm{pH} 7.2)$. SPM or SJ fractions were then resuspended at 1 to $2 \mu \mathrm{g} / \mu \mathrm{l}$ in $50 \mathrm{~mm}$ Tris- $\mathrm{HCl}(\mathrm{pH} 7.0), 0.5 \mathrm{~mm}$ DTT. Twoto 4-hr treatments with NaF/EDTA irreversibly inhibited endogenous phosphatase activity in synaptic fractions without significantly affecting CaMkinase II activity (see "Results").

Preparation of proteins and ${ }^{32}$ P-protein substrates. Phosphorylase $b$ (Fischer and Krobs, 1958), phosphorylasc kinaso (Cohen, 1973), inhibitor 1 (Nimmo and Cohen, 1978), inhibitor-2 (Foulkes and Cohen, 1980), and catalytic subunits of PrP-1 and PrP-2A (Lim Tung et al., 1984) were purified to hornogeneity as previously described. CaM-kinase II was purified as described elsewhere (Kelly et al., 1984). Synapsin I and the catalytic subunit of cAMP-dependent protein kinase were generous gifts from Teresa McGuinness and Paul Greengard (Rockefeller University), and Jim Maller (University of Colorado Health Sciences Center), respectively.

${ }^{32} \mathrm{P}$-Phosphorylase a and phosphorylase kinase were prepared and freed 
of unreacted [ $\gamma^{32}$ P]ATP as previously described (Ingebritsen and Cohen 1983b). ${ }^{32} \mathrm{P}$-CaM-kinase II $\left(1.5 \times 10^{5} \mathrm{cpm} / \mu \mathrm{g}\right)$ and synapsin I $\left(5 \times 10^{4} \mathrm{cpm} /\right.$ $\mu \mathrm{g})$ were prepared by incubation of CaM-kinase II $(2 \mu \mathrm{g})$ in the presence or absence of synapsin I $(25 \mu \mathrm{g})$ in reactions containing CaM $(2 \mu \mathrm{g}), 200 \mu \mathrm{M}$ $\mathrm{CaCl}_{2}, 5 \mathrm{~mm} \mathrm{Mg}{ }^{2+}, 20 \mu \mathrm{M}\left[\gamma^{-32} \mathrm{P}\right]$ ATP $\left(3.7 \times 10^{9} \mathrm{cpm} / \mu \mathrm{mol}\right)$, in a final volume of $100 \mu \mathrm{l}$.

Assay of type 1 and type 2 protein phosphatase activities in subcellular fractions. Protein phosphatase assays were carried out as in Ingebritsen et al. (1983c), and the release of ${ }^{32} \mathrm{P}_{\mathrm{i}}$ from ${ }^{32} \mathrm{P}$-labeled substrate proteins was measured as previously described (Foulkes and Cohen, 1980). PrP-1 and PrP-2A are the only protein phosphatases having significant phosphorylase a phosphatase activity (Ingebritsen and Cohen, 1983b; Ingebritsen et al.. 1983b). They were therefore assayed using ${ }^{32} \mathrm{P}$-phosphorylase a $(1 \mathrm{mg} / \mathrm{ml})$ as a substrate in the presence and absence of inhibitor-2 (100 units/assay; see Foulkes and Cohen, 1980, for definition of units) as previously described (Ingebritsen et al., 1983c). Assays were carried out in the presence of $1 \mathrm{~mm}$ free $\mathrm{Mn}^{2+}$ for reasons described elsewhere (Ingebritsen et al., 1983b). Fractions were assayed at the highest possible dilution (1:150 to 1:300) to prevent possible interference by high and low molecular weight inhibitors of protein phosphatases (Stewart et al., 1983). PrP-2A activity was taken as the phosphorylase a phosphatase activity in the presence of inhibitor-2. PrP-1 activity is the difference between the phosphorylase a phosphatase activities observed in the absence and presence of inhibitor-2. One unit of PrP-1 or PrP.2A was the amount of activity that released $1 \mathrm{nmol}$ of $\mathrm{P}_{\mathrm{i}}$ from phosphorylase $a$ in $1 \mathrm{~min}$ at $30^{\circ} \mathrm{C}$.

PrP-2B and PrP-2C were assayed using $0.4 \mu \mathrm{M}$ 32 P-phosphorylase kinase (containing approximately $0.9 \mathrm{~mol}$ of phosphate $/ \mathrm{mol}$ of each $\alpha$ - and $\beta$ subunit) as substrate. The activity of PrP-2B was measured in the presence of $1 \mathrm{~mm}$ free $\mathrm{Mn}^{2+}$ and $1 \mu \mathrm{M}$ CaM. Activity was taken as the difference between the activities observed in the absence and presence of $100 \mu \mathrm{M}$ trifluoperazine (Ingebritsen et al., 1983b). $\mathrm{Mn}^{2+}$ can substitute for $\mathrm{Ca}^{2+}$ in the activation of PrP-2B. Stewart et al. (1983) found that during the latter stages of purification PrP-2B was converted to a form that had low specific activity in the presence of $\mathrm{Ca}^{2+}$. The enzyme's activity was restored when assays were carried out in the presence of $\mathrm{Mn}^{2+}$. In pilot studies we found that PrP. $2 \mathrm{~B}$ activity in cytosolic fractions was 5-fold lower in the presence of $\mathrm{Ca}^{2+}$ compared to $\mathrm{Mn}^{2+}$. Consequently, $\mathrm{Mn}^{2+}$ was used in assays to increase their sensitivity. The activity of PrP-2C was assessed after treating fractions with $\mathrm{NaF}(50 \mathrm{~mm})$ and EDTA $(10 \mathrm{~mm})$ to inactivate PrP-2A (Ingebritsen et al., $1983 \mathrm{~b}, \mathrm{c})$. PrP-2C activity was taken as the difference between phosphorylase kinase phosphatase activities in the presence of $10 \mathrm{~mm} \mathrm{Mg}^{2+}$ plus 1.0 $\mathrm{mM}$ EGTA or in the presence of $1.0 \mathrm{~mm}$ EGTA alone. Assays for PrP-2B and PrP-2C contained inhibitor-2 (100 units) to block background activity due to PrP-1. One unit of PrP-2B or PrP-2C activity is that amount that releases 1 $\mathrm{nmol}$ of $\mathrm{P}_{\mathrm{i}}$ from phosphorylase kinase in $1 \mathrm{~min}$ at $30^{\circ} \mathrm{C}$. The activity of PrP. 2B was extrapolated to $V_{\max }$ using a $K_{\mathrm{m}}$ value of $5.9 \mu \mathrm{M}$ (Stewart et al., 1983).

Western blots. Electrophoretic transfer and immunostaining of nitrocellulose sheets were carried out as previously described (Kelly et al., 1984).

\section{Results}

Dephosphorylation of SJ and SPM phosphoproteins by endogenous PrPs. As a first step toward investigating phosphatase-like activities in synaptic fractions, SPM and SJ proteins phosphorylated by endogenous CaM-kinase II were used as substrates. Endogenous phosphatase activity was assessed by measuring the removal of ${ }^{32} \mathrm{P}$-phosphate from ${ }^{32} \mathrm{P}$-phosphoproteins in SJs. The phosphatase activity in SJs dephosphorylated both 50- and 60-kd CaM-kinase II polypeptides as well as four additional SJ phosphoproteins of 240, 207, 170, and $140 \mathrm{kd}$ (Fig. 1, lanes $c$ and $d$ ). In general, the rate and extent of dephosphorylation of these phosphoproteins were similar. SPM fractions contained the same prominent phosphoproteins observed in SJ fractions and displayed very similar properties of endogenous protein dephosphorylation (Fig. 1, lanes $a$ and b), despite the observation that the specific activity of CaM-kinase II in SPMs toward endogenous proteins was approximately 20 -fold lower than that in SJs (Kelly et al., 1985).

The phosphatase(s) in SJ fractions effectively dephosphorylated exogenous ${ }^{32} \mathrm{P}$-synapsin I; $80 \%$ of the radioactivity in ${ }^{32} \mathrm{P}$-synapsin I $(0.5 \mu \mathrm{g})$ was removed by $20 \mu \mathrm{g}$ of SJs during $30 \mathrm{~min}$ at $30^{\circ} \mathrm{C}$. Likewise, SJ fractions rapidly dephosphorylated exogenous ${ }^{32} \mathrm{P}$ CaM-kinase II (results not shown). These findings demonstrated that particulate-associated phosphatases in SJs can physically interact

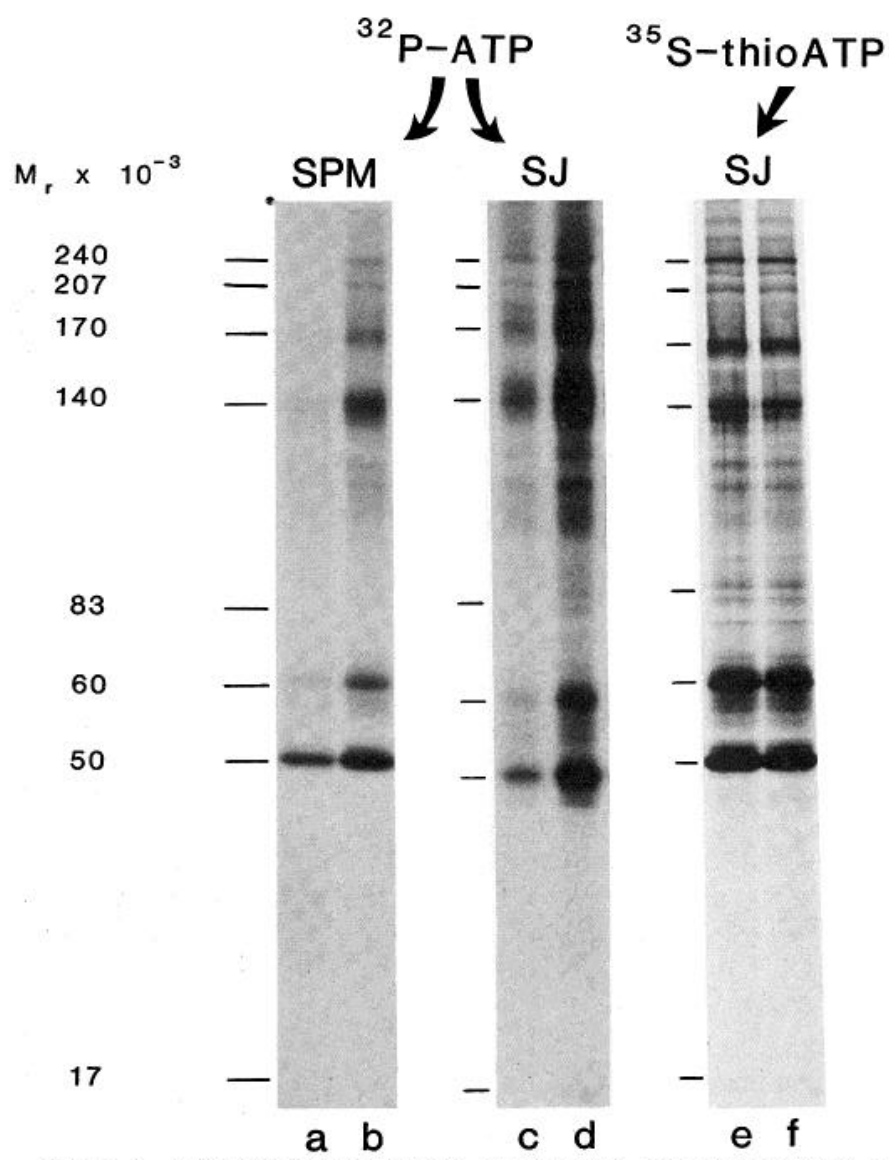

Figure 1. Autoradiograms showing endogenous dephosphorylation of SPM $(a$ and $b)$ and $S J(c$ to $f)$ phosphoproteins. SPM and SJ proteins were phosphorylated in vitro with their respective endogenous. CaM-kinase II using either [ $\gamma{ }^{32}$ P]ATP (lanes a to $d$ ) or [thio- ${ }^{35}$ S]ATP (lanes e and $f$ ). SPMs and $\mathrm{S} J \mathrm{~s}$ were then washed by centrifugation to remove ATP, $\mathrm{Ca}^{2+}$, and $\mathrm{CaM}$, resuspended in dephosphorylation buffer, and incubated at either $37^{\circ} \mathrm{C}$ (lanes $a, c$, and $e$ ) or $4^{\circ} \mathrm{C}$ (lanes $b, d$, and $f$ ) for $60 \mathrm{~min}$. The left lane of each pair displays the degree of temperature-dependent endogenous dephosphorylation in each synaptic fraction. Autoradiographic exposures were $190 \mathrm{hr}$ for lanes $a$ and $b, 8 \mathrm{hr}$ for lanes $c$ and $d$, and $120 \mathrm{hr}$ for lanes $e$ and $f$ (approximate molecular weights are indicated in the margin).

with and dephosphorylated soluble ${ }^{32} \mathrm{P}$-synapsin I and CaM-kinase II.

To confirm that the removal of ${ }^{32} \mathrm{P}$-phosphate from phosphorylated proteins was due to protein phosphatase activity and not proteolytic degradation, ${ }^{32} \mathrm{P}$-SJs were incubated at either $4^{\circ} \mathrm{C}$ or $37^{\circ} \mathrm{C}$ for varying lengths of time before terminating reactions by the addition of SDS followed by precipitation of proteins with TCA. ${ }^{32} \mathrm{P}$-inorganic phosphate liberated in these reactions was quantitatively separated from ${ }^{32}$ P]ATP and ${ }^{32}$ P-peptides by its association with molybdate and subsequent partitioning in a two-phase system (see "Materials and Methods"). TCA-insoluble ${ }^{32} \mathrm{P}$-proteins from the same reactions were solubilized in SDS sample buffer, separated by SDS-PAGE, and analyzed by autoradiography. Densitometric scanning of autoradiograms was used to quantitate the extent of dephosphorylation for individual SJ proteins. This analysis demonstrated removal of ${ }^{32} \mathrm{P}$. phosphate from all SJ phosphoproteins and a concomitant appearance of ${ }^{32} \mathrm{P}$-phosphate in the supernatant; these two indices of protein dephosphorylation were inversely related but of equivalent magnitude (Fig. 2). Figure 2 shows the very. similar rates of endogenous dephosphorylation for the 50- and 60-kd phosphoproteins of CaM-kinase II. The other major phosphoproteins in SJs that are substrates for CaM-kinase II were dephosphorylated at rates similar to those observed for the 50 - and 60 -kd proteins (results not shown). 
TX-sol SPM fractions displayed very similar temperature-dependent phosphatase activity when compared to SJs; the former activity was measured using ${ }^{32} \mathrm{P}$-SJs as substrate (results not shown). Control experiments demonstrated that the endogenous dephosphorylation of ${ }^{32} \mathrm{P}$-proteins was not affected by the concentration of TX present in the different assays.

Table I (top) shows the results from experiments using ${ }^{32} \mathrm{P}-\mathrm{S} J \mathrm{~s}$ (intact) to examine the action of endogenous protein phosphatases on the dephosphorylation of 60- and 50-kd phosphoproteins of $\mathrm{CaM}$ kinase $\|$ in the presence of a battery of protease inhibitors. When the inhibitors PMSF, leupeptin, pepstatin, and $\alpha$-2-macroglobulin were included in reaction buffers, no effect on the rate or extent of endogenous dephosphorylation of 60- and 50-kd SJ proteins was obscrved. Likcwise, the addition of TX-sol SPMs and phosphatases

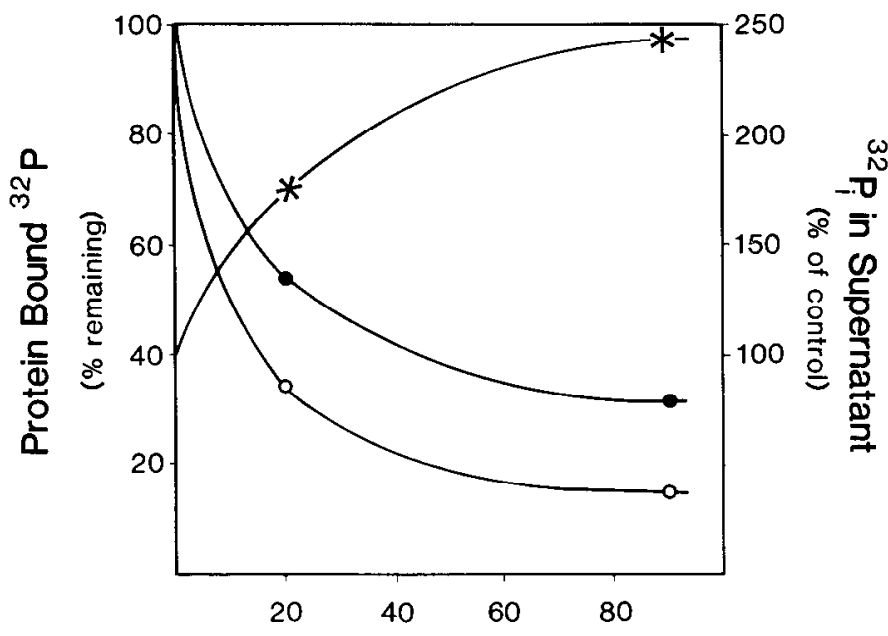

\section{time at $37^{\circ} \mathrm{C}(\mathrm{min})$}

Figure 2. Removal of ${ }^{32} \mathrm{P}$-phosphate from SJ phosphoproteins by endogenous phosphatases. SJ proteins were phosphorylated by endogenous CaMkinase II for $1 \mathrm{~min}$ at $30^{\circ} \mathrm{C}$ (see "Materials and Methods"). The removal of ${ }^{32} \mathrm{P}$-phosphate from the $50-\mathrm{kd}(\mathbf{)}$ and $60 \mathrm{kd} \mathrm{(O)} \mathrm{phosphoproteins} \mathrm{of} \mathrm{CaM-}$ kinase $I I_{1}$ and the simultaneous appearance of ${ }^{32} \mathrm{P}$ in the supernatants $(*)$ were determined by gel electrophoresis/autoradiography and molybdate phase-partitioning, respectively (see "Materials and Methods). ${ }^{32} \mathrm{P}$-labeled SJs (47 $\mu \mathrm{g}$ of protein) were incubated at $37^{\circ} \mathrm{C}$ in $80 \mu$ l of dephosphorylation buffer for various lengths of time. Experimental values for protein dephosphorylation were calculated based on control reactions carried out at $4^{\circ} \mathrm{C}$; the latter conditions reduced endogenous phosphatase activity by greater than $95 \%$. Values represent the averages of triplicate determinations; individual data points differed less than $10 \%$ from each other. contained therein to accelerate the rate of dephosphorylation of ${ }^{32} \mathrm{P}$ SJ proteins was unaffected by the addition of protease inhibitors (Table I, bottom). In agreement with these findings, no changes in Coomassie blue or silver staining patterns of SJ proteins were observed following dephosphorylation reactions, except for the 50 and 60-kd phosphoproteins of CaM-kinase II (results not shown). These bands became narrower and were shifted to slightly lower molecular weights upon dephosphorylation. Previous studies have shown that the apparent molccular wcights of the subunits of $\mathrm{CaM}$ kinase II phosphoproteins increase as a result of being phosphorylated in a Ca ${ }^{2+} / \mathrm{CaM}$-dependent manner (Kelly et al., 1984; Shields et al., 1984).

When ${ }^{35} \mathrm{~S}$-thiophosphorylated SJ proteins were used as substrates in experiments examining endogenous and/or exogenous PrP activities, a dramatic decrease in the extent of dephosphorylation was observed (Fig. 1, lanes e and $f$ ). ${ }^{35}$ S-thiophosphorylated SJ proteins were refractory to phosphatase activity and retained greater than $96 \%$ of their radioactivity following 90 -min dephosphorylation reactions at $37^{\circ} \mathrm{C}$. This finding is in agreement with the reported resistance of thiophosphorylated proteins to the action of protein phosphatases (Sherry et al., 1978; Hoar et al., 1979; Cassel and Glaser, 1982).

Endogenous phosphatase activities in synaptic fractions were irreversibly inactivated by incubating $S J s$ in $50 \mathrm{~mm} \mathrm{NaF}, 0.5 \mathrm{~mm}$ EDTA for $180 \mathrm{~min}$ at $4^{\circ} \mathrm{C}$ (Fig. 3 , lanes $b$ and $\mathrm{c}$ ). This treatment is known to inactivate PrP-1 and PrP-2A (Ingebritsen et al., 1983a, b) and resulted in greater than $98 \%$ inactivation of phosphatase activity in synaptic fractions. Control experiments demonstrated that this treatment did not inactivate CaM-kinase II activity in SJs if care was taken to remove $\mathrm{NaF}$ and EDTA prior to phosphorylating SJ proteins by endogenous CaM-kinase II (Fig. 3, lane $d$ ). SJs prephosphorylated with $\left[\gamma^{-32}\right.$ P]ATP and then treated with NaF/EDTA to inactivate phosphatases contained phosphoproteins that were good substrates for phosphatases present in TX-sol SPM fractions (Fig. 3, lane $h$ ), or purified PrP-1 and PrP-2A (see below).

Identity of endogenous PrPs. The distribution of type-1 and type2 PrPs in subcellular fractions from rat forebrain is presented in Table II. The specific activity of PrP-1, $-2 \mathrm{~A}$, and $-2 \mathrm{~B}$ was 1.5 - to 5-fold higher in synaptosol compared to cytosol fractions, whereas that of PrP-2C was similar in these two fractions. The specific activity of PrP-1 was slightly lower (1.5- to 2-fold) in SPM and SJ fractions cornpared to synaplosol. In contrast, the specific activity of the type2 phosphatases was dramatically lower in SPM and SJ fractions compared to cytosol. Thus, the ratio of PrP-1 to PrP-2A activities was approximately 10 -fold higher in the SPM and SJ fractions compared to cytosolic and synaptosolic fractions. Type- 1 and type2 phosphatases were detected in TX-sol SPM fractions, the specific activity of the former being the highest.

TABLE I

Percentage decrease in ${ }^{32} P$ content of SJ phosphoproteins

Endogenous dephosphorylation of SJ phosphoproteins was demonstrated by the percentage decreases in ${ }^{32} \mathrm{P}$ associated with 60 - and ${ }^{50} \mathrm{kd} \mathrm{SJ}$ phosphoproteins following incubations at $37^{\circ} \mathrm{C}$ under various conditions. Ten micrograms of ${ }^{32} \mathrm{P}$-labeled SJs were used in each reaction. Reactions contained buffer alone, or the following additions: $\mathrm{CaM}(2 \mu \mathrm{g} / 100 \mu \mathrm{l}), \mathrm{CaCl}_{2}(2 \mathrm{mM}), \mathrm{MgCl}_{2}(2 \mathrm{~mm})$, or EGTA (5 mM). Dephosphorylation reactions were in $45 \mu \mathrm{l}$ of buffer containing $50 \mathrm{~mm}$ Tris-HCl, $0.5 \mathrm{~mm} \mathrm{DTT} \mathrm{(pH} \mathrm{7.0);} \mathrm{some} \mathrm{reactions} \mathrm{also} \mathrm{contained} \mathrm{the} \mathrm{protease} \mathrm{inhibitors} \mathrm{PMSF} \mathrm{(1.5} \mathrm{mM),} \mathrm{leupeptin} \mathrm{(10} \mu \mathrm{g} / \mathrm{ml})$, pepstatin A $(10 \mu \mathrm{g} / \mathrm{ml})$, and $\alpha-2$-macroglobulin $(25 \mu \mathrm{g} / \mathrm{ml})$. TX-sol SPMs $(10 \mu \mathrm{g}$ of protein) were added to certain reactions as indicated. Percentage decreases were computed by comparison of $37^{\circ} \mathrm{C}$ reactions to their appropriate $4^{\circ} \mathrm{C}$ control. All percentages are averages of two or more experiments; values between experiments varied less than $10 \%$ from each other.

\begin{tabular}{ccccccc}
\hline Protein Band $(\mathrm{kd})$ & Time (minutes) & Buffer $(\%)$ & Protease Inhibitors (\%) & CaM/Ca $^{2+}(\%)$ & $\mathrm{Mn}^{2+}(\%)$ & $\mathrm{EGTA}^{(\%)}$ \\
\hline 60 & 45 & -58 & -58 & -55 & -71 & -57 \\
50 & 45 & -61 & -60 & -50 & -67 & -58 \\
\hline & Time (minutes) & Buffer (\%) & $\mathrm{Mg}^{2+}(\%)$ & TX-sol SPMs (\%) & Protease Inhibitors (\%) \\
\hline 60 & 20 & -27 & -26 & -57 & -58 \\
50 & 20 & -23 & -24 & -52 & -53 \\
\hline
\end{tabular}




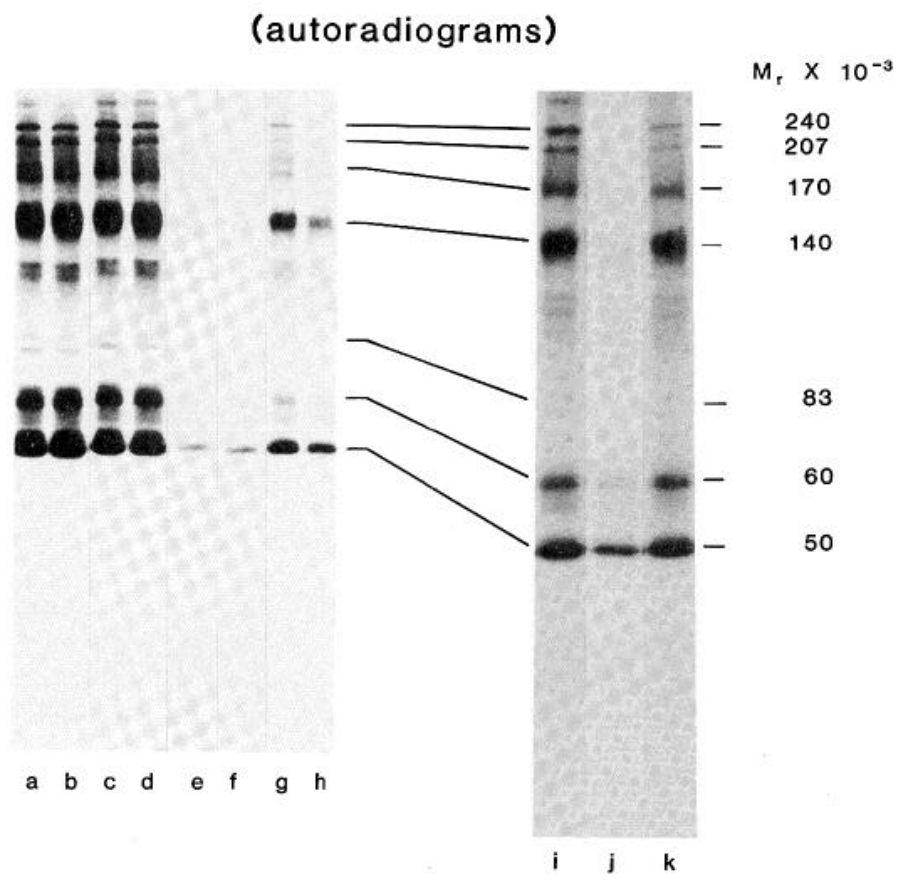

Figure 3. Autoradiograms showing dephosphorylation of ${ }^{32} \mathrm{P}$-labeled $\mathrm{SJ}$ proteins under different in vitro conditions. SJ proteins were phosphorylated by endogenous CaM-kinase II using [ $\gamma^{32}$ P]ATP. Each lane contains $20 \mu \mathrm{g}$ of protein from SJs that were subjected to different dephosphorylation conditions. Lanes a to $h$ contain ${ }^{32}$-labeled SJs from an individual experiment: lane $a,{ }^{32} \mathrm{P}$-labeled SJs incubated for $120 \mathrm{~min}$ at $4^{\circ} \mathrm{C}$; lane $b,{ }^{32} \mathrm{P}$. labeled SJs treated with NaF/EDTA and then incubated for 120 min at $4^{\circ} \mathrm{C}$; lane $c$, ${ }^{32} \mathrm{P}$-labeled SJs treated with NaF/EDTA and then incubated for 120 min at $37^{\circ} \mathrm{C}$; lane $d$, SJs pretreated with NaF/EDTA prior to being phosphorylated with endogenous CaM-kinase ॥ (NaF/EDTA pretreatment had no apparent affect on CaM-kinase II activity); lane $e,{ }^{32} \mathrm{P}$-labeled SJs treated with $\mathrm{NaF} / E D T A$ and then incubated for $120 \mathrm{~min}$ at $37^{\circ} \mathrm{C}$ in the presence of PrP. 2A (0.6 units/ml); lane $f,{ }^{32}$ P-labeled SJs treated with NaF/EDTA and then incubated for $120 \mathrm{~min}$ at $37^{\circ} \mathrm{C}$ in the presence of PrP-1 $(0.6$ units $/ \mathrm{ml})$; lane $g$, ${ }^{32} \mathrm{P}$-labeled SJs incubated for $60 \mathrm{~min}$ at $37^{\circ} \mathrm{C}$ without pretreatment in $\mathrm{NaF} /$ EDTA (endogenous phosphatases are fully active in this SJ fraction); and lane $h,{ }^{32} \mathrm{P}$-labeled SJs incubated for $60 \mathrm{~min}$ at $37^{\circ} \mathrm{C}$ in the presence of 10 $\mu \mathrm{g}$ of TX-sol SPMs (these SJs were not pretreated with NaF/EDTA). Lanes $i$ to $k$ contain ${ }^{32} \mathrm{P}$-labeled SJs from an experiment which examined the affects of exogenous PrP inhibitors on endogenous phosphatase activity: lane $i$, ${ }^{32} \mathrm{P}$. labeled S.Js incubated $90 \mathrm{~min}$ at $4^{\circ} \mathrm{C}$; lane $j$, ${ }^{32} \mathrm{P}$-labeled SJs incubated 90 min at $37^{\circ} \mathrm{C}$; and lane $k,{ }^{32} \mathrm{P}$-labeled SJs incubated $90 \mathrm{~min}$ at $37^{\circ} \mathrm{C}$ in the presence of PrP inhibitors $1-1$ and $1-2$ (both at 3.4 units $/ \mu \mathrm{l}$ ).
The possible functional interaction between PrP-1 or PrP-2A and ${ }^{32} \mathrm{P}$-phosphoproteins in SJ fractions was investigated. Homogeneous preparations of these PrPs were added to ${ }^{32} \mathrm{P}$-SJs that had been pretreated with $\mathrm{NaF} / \mathrm{EDTA}$ to inactivate endogenous phosphatase activity. Both PrP-1 and PrP-2A dephosphorylated SJ phosphoproteins to a significant extent; within $60 \mathrm{~min}$ at $37^{\circ} \mathrm{C}, 0.03$ units of either PrP-1 or PrP-2A removed greater than $90 \%$ of the radioactive phosphate from $20 \mu \mathrm{g}$ of ${ }^{32} \mathrm{P}$-SJs (Fig. 3, lanes e and $f$; Table III). PrP-1 and $-2 \mathrm{~A}$ were equally effective in dephosphorylating ${ }^{32} \mathrm{P}-\mathrm{SJ}$ phosphoproteins. Dephosphorylation reactions containing PrP-1 and PrP-2A and carried out for longer durations (120 min) resulted in greater than $98 \%$ dephosphorylation of all ${ }^{32} \mathrm{P}-\mathrm{SJ}$ proteins (results not shown).

Having established that PrP-1 and PrP-2A were present in SJ fractions and that both were capable of dephosphorylating SJ proteins, we were interested in determining what proportion each contributed to the total phosphatase activity in SJs. This was accomplished by examining the extent of endogenous protein dephosphorylation in synaptic fractions in the presence of exogenous inhibitor1 and -2 , both of which specifically inhibit PrP-1. Phosphoinhibitor-1 was used; the latter is active only when phosphorylated. The effects of inhibitors on endogenous SJ phosphatase activity are shown in Figure 3 (lanes $i$ to $k$ ) and Table IV. When inhibitor-1 and inhibitor-2 were used together, the endogenous phosphatase activity in SJs was inhibited approximately $80 \%$. In similar experiments, the endogenous phosphatase activities in SPMs and TX-sol SPMs were inhibited approximately $84 \%$ and $53 \%$, respectively. Similar results

\section{TABLE III}

Effects of exogenous phosphatases on the dephosphorylation of ${ }^{32} \mathrm{p}$ labeled SJ proteins

Reactions measured the extent of dephosphorylation of NaF/EDTA-treated ${ }^{32} \mathrm{P}$-labeled SJs ( $8.5 \mu \mathrm{g} /$ reaction) by purified PrP-1 and PrP-2A. Reactions $(50 \mu \mathrm{l})$ were carried out at $37^{\circ} \mathrm{C}$. Experiments were done in duplicate using three separate preparations of SJs. Values represent averages for 140-, $60-$, and $50-\mathrm{kd}$ phosphoproteins; values (percentage of dephosphorylation) for individual phosphoproteins varied less than $15 \%$ from each other.

\begin{tabular}{lcc}
\hline \multirow{2}{*}{ Condition } & \multicolumn{2}{c}{$\begin{array}{c}\text { Percentage of }{ }^{32} \mathrm{P} \\
\text { Remaining }\end{array}$} \\
\cline { 2 - 3 } & $15 \mathrm{~min}$ & $60 \mathrm{~min}$ \\
\hline No addition & 100 & 93 \\
PrP-1 & 43 & 10 \\
$(0.03$ units $)$ & 55 & 5 \\
PrP-2A & & \\
$(0.03$ units $)$ & & \\
\hline
\end{tabular}

TABLE ॥

Distribution of type-1 and type-2 PrPs in subcellular fractions from rat forebrain

Values represent the mean specific activities (units $(U)$ per milligram of protein) from two or three separate preparations of each fraction. The range or SEM is given. Phosphatase assay conditions, preparation of subcellular fractions, and activity units are described under "Materials and Methods." Note that the specific activity of PrP-2C is expressed in milliunits per milligram of protein.

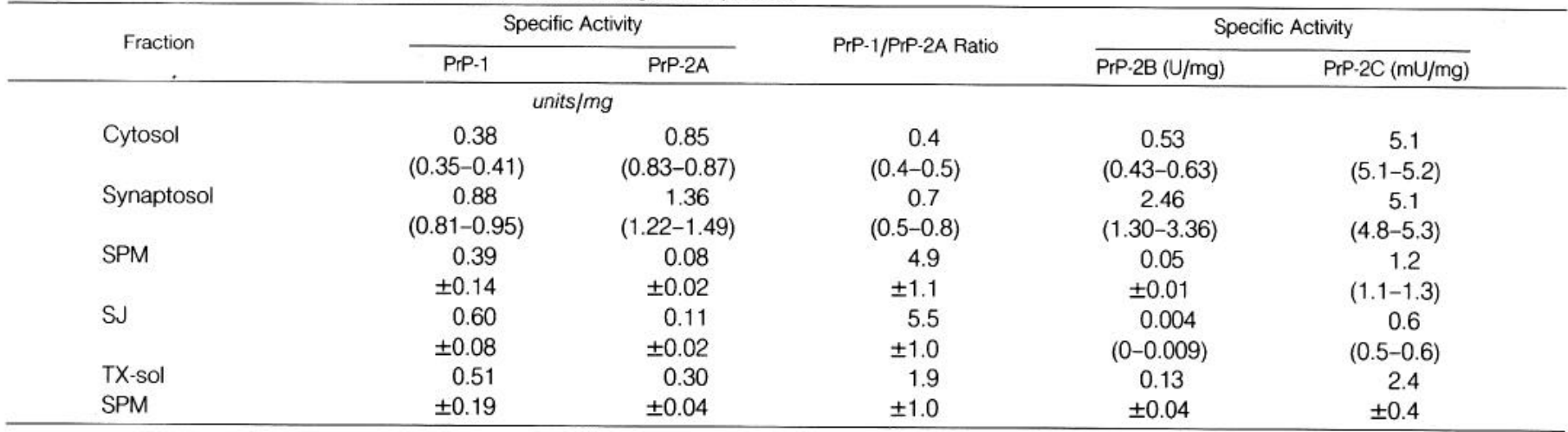


TABLE IV

Effects of exogenous phosphatase inhibitors on PrP activities in synaptic fractions

Results are expressed as percentage of ${ }^{32} \mathrm{P}$ lost from subcellular fractions after incubations at $37^{\circ} \mathrm{C}$ in the absence (buffer) or presence of inhibitors-1 and -2 (170 units each per reaction). The degree of phosphatase inhibition is indicated as a percentage of total ${ }^{32} \mathrm{P}$ removal that was inhibited by inhibitors-1 + -2. Reactions were carried out in $50 \mu \mathrm{l}$ and contained either ${ }^{32}$ P-labeled SJs $(20 \mu \mathrm{g})$ or SPMS $(30 \mu \mathrm{g})$; TX-sol SPM fractions were used at $10 \mu \mathrm{g} /$ reaction. Values are averages for the $170-, 140-, 60-$ and $50-\mathrm{kd} \mathrm{SJ}$ or SPM phosphoproteins; values (percentage of dephosphorylation) for individual phosphoproteins varied less than $10 \%$ from each other.

\begin{tabular}{lcccc}
\hline \multirow{2}{*}{ Fraction } & $\begin{array}{c}\text { Time } \\
\text { (minutes) }\end{array}$ & \multicolumn{2}{c}{ Percentage of ${ }^{32} \mathrm{P}$ Lost } & $\begin{array}{c}\text { Percentage } \\
\text { Inhibition }\end{array}$ \\
\cline { 5 - 6 } SPM & 30 & 50 & 8 & 84 \\
& 90 & 74 & 30 & 60 \\
SJ & 30 & 50 & 10 & 80 \\
& 90 & 80 & 50 & 38 \\
\multirow{2}{*}{ SJ plus TX-sol SPMS } & 30 & 60 & 28 & 53 \\
& 90 & 69 & 46 & 33 \\
\hline
\end{tabular}

were observed with either inhibitor- 1 or -2 . Measurements of the extent of dephosphorylation at longer reaction times (greater than $45 \mathrm{~min}$ ) and in the presence of inhibitors were less accurate than values at shorter times because non-PrP-1 phosphatases remained active. These findings indicate that, of the total protein phosphatase activity in SPM or SJ fractions, PrP-1 constitutes the major activity. The remaining activity is probably due to PrP-2A (see below).

Experiments were carried out to determine whether PrP-2B or PrP$2 \mathrm{C}$ contributed to the endogenous protein phosphatase activity toward SJ proteins phosphorylated by endogenous CaM-kinase II. PrP-2B is completely dependent on $\mathrm{Ca}^{2+}$ or $\mathrm{Mn}^{2+}$ (see "Materials and Methods") for activity toward all known substrates, and its activity is stimulated 10-fold by CaM (Stewart et al., 1983). As shown in Table I, $\mathrm{Ca}^{2+}$ plus CaM did not stimulate PrP activity in SJ fractions; moreover, endogenous activity was not inhibited by EGTA. Mn $^{2 i}$ was found to stimulate slightly (5 to $10 \%$ ) the dephosphorylation of ${ }^{32} \mathrm{P}$-proteins in S.Js by endogenous PrP activity (Table I). However, the activity of PrP-1 and PrP-2A using phosphorylase $a$ as substrate was also stimulated by $\mathrm{Mn}^{2+}$ (Table II; see "Materials and Methods"). These results suggest that PrP-2B does not make a significant contribution to the endogenous dephosphorylation of SJ phosphoproteins. Further experiments (see Table I) indicated that PrP activity in SJs was not stimulated by $\mathrm{Mg}^{2+}$. Since PrP-2C is completely dependent on $\mathrm{Mg}^{2+}$ for activity (Pato et al., 1983), this enzyme does not contribute to the endogenous phosphatase activily in SJ fractions.

Additional experiments examined cytosolic fractions $(100,000 \times$ $g$ supernatants) from brain homogenates and hypotonic lysates of synaptosomal fractions for protein phosphatase activity. Dephosphorylation reactions contained cytosolic proteins and ${ }^{32} \mathrm{P}$-SJ fractions phosphorylated by endogenous CaM-kinase II ( ${ }^{32} \mathrm{P}$-SJs were pretreated with $\mathrm{NaF} / \mathrm{EDTA}$ prior to dephosphorylation reactions). ${ }^{32} \mathrm{P}$ labeled SJs incubated with cytosolic or synaptoplasmic fractions lost $19 \%$ and $44 \%$ of their ${ }^{32} \mathrm{P}$ during $30 \mathrm{~min}$ at $37^{\circ} \mathrm{C}$, respectively (results not shown). Synaptoplasmic fractions routinely contained 2 to 4-fold more phosphatase activity per microgram of protein than did conventional cytosolic fractions.

Commercially available alkaline phosphatases from $E$. coli, bovine intestine, and human placenta, as well as acid phosphatases from potato and human semen, were examined for their ability to dephosphorylate purified ${ }^{32} \mathrm{P}$-CaM-kinase II (see "Materials and Methods"). None of these phosphatases demonstrated detectable activity in removing protein-bound ${ }^{32} \mathrm{P}$-phosphate from CaM-kinase II. Likewise, these phosphatases were incapable of dephosphorylating ${ }^{32} \mathrm{P}$-phosphoproteins in intact SJs (results not shown). In contrast, when ${ }^{32} \mathrm{P}$ SJs were solubilized in $1 \%$ SDS and then incubated with these different phosphatases (after diluting SDS to $0.05 \%$ ), only the alkaline phosphatase from bovine intestine $(10$ units $/ \mathrm{ml})$ displayed moderate activity in dephosphorylating ${ }^{32} \mathrm{P}$-SJ proteins; the rate of dephosphorylation in these reactions was half of that observed for endogenous phosphatases acting on ${ }^{32}$ P-proteins in "intact" SJs. These results show that SJ phosphoproteins are very poor substrates for a number of alkaline and acid phosphatases from non-neuronal tissues.

Independent measurement of PrP-2B (calcineurin) in synaptic fractions. The very low specific activity of calcineurin in $S J$ fractions (Table II) was surprising in light of previous findings which demonstrated by immunohistochemical methods that calcineurin was present in postsynaptic densities in fixed neural tissues (Wood et al., 1980). Since it was possible that the fractionation procedures used to isolate SJs may have inactivated any calcineurin present in synaptic structures in situ, a Western blot analysis of synaptic fractions was undertaken using an affinity-purified antibody against calcineurin (kindly provided by Dr. Claude Klee, National Institutes of Health, Bethesda, MD). The amount of calcineurin in SJ fractions was 11 -fold lower than that in SPMs; the former contained $0.21 \mu \mathrm{g}$ of calcineurin per milligram of protein (Fig. 4). Approximately $95 \%$ of the calcineurin in SPM fractions was recovered in the Tritonsoluble extract of SPMs. Calcineurin was detected in all subcellular fractions and was present in synaptosol-enriched fractions (L-S3) in the highest relative concentration $(9.36 \mu \mathrm{g}$ of calcineurin $/ \mathrm{mg}$ of protein). The calcineurin content of forebrain homogenate and SPM fractions was equivalent ( $2.3 \mu \mathrm{g}$ of calcineurin $/ \mathrm{mg}$ of protein). In general, values for the relative concentration of calcineurin in subcellular fractions from Western blot analysis were similar to those from $\mathrm{PrP}-2 \mathrm{~B}$ activity measurements (see Table II), with the exception that calcineurin activity values using SPM fractions were consistently lower than soluble fractions when compared to ratios based on antibody binding (Fig. 4). Results from ${ }^{125}$-peptide mapping experiments have confirmed the near absence of calcineurin in SJ fractions (P. T. Kelly, unpublished observations).

Experiments using ${ }^{32} \mathrm{P}$-labeled SJs demonstrated that purified and active calcineurin (kindly provided by Dr. Claude Klee) displayed very little, if any, $\mathrm{Ca}^{2+} / \mathrm{Mn}^{2+}$-dependent and CaM-stimulated activity in dephosphoryating the 240-, 207-, 170-, and 140-kd proteins phosphorylated by endogenous CaM-kinase II when added at concentrations similar to those used for PrP-1 (results not shown). Calcineurin did not dephosphorylate the autophosphorylated subunits of CaM-kinase II to any appreciable extent. These results agree with the observation that purified CaM-kinase II is dephosphorylated 50-fold less effectively by calcineurin when compared to equivalent amounts of PrP-2A and PrP-1 (A. Nairn, personal communication).

\section{Discussion}

Our results demonstrate the presence of protein phosphatase activity in synaptic fractions from rat forebrain. The endogenous PrP activity in SJ and SPM fractions was shown to dephosphorylate most, if not all, endogenous proteins that are phosphorylated by endogenous CaM-kinase II. Removal of ${ }^{32}$ P-phosphate from endogenously phosphorylated SJ proteins by proteolysis was ruled out by a TCA-molybdate phase-partitioning assay that specifically measures ${ }^{32} \mathrm{P}_{\mathrm{i}}$ release, and the activity of $\mathrm{SJ}$ phosphatases was unaffected by a broad battery of protease inhibitors. Moreover, observations that the protein-staining patterns of SJs remained virtually unchanged following a variety of dephosphorylation conditions indicated that proteolytic release of ${ }^{32} \mathrm{P}_{i}$ was most unlikely. The endogenous phosphatase activity in SJ fractions displayed irreversibie inactivation by $\mathrm{NaF} /$ EDTA, a property shared by PrP 1 and PrP 2A (Ingebritsen ct al., 1983b, c). Finally, ${ }^{35}$ S-thiophosphorylated proteins in SJs were virtually resistant to dephosphorylation by endogenous phosphatases, a characteristic typical of other known thiophosphorylated 


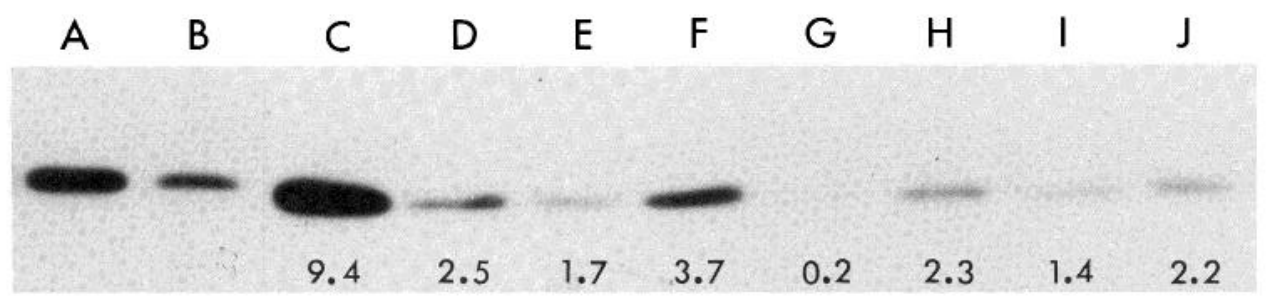

Figure 4. Western blot analysis of subcellular fractions from rat brain and purified calcineurin. Fractions were separated by SDS-PAGE and transferred to nitrocellulose. The 50- to 70-kd regions of nitrocellulose sheets were then incubated in affinity-purified anti-calcineurin (rabbit lgG, approximately $0.8 \mu \mathrm{g} / \mathrm{ml}$ ) followed by ${ }^{125}$-protein $\mathrm{A}\left(2 \times 10^{6} \mathrm{cpm} / \mathrm{ml}, 2 \mu \mathrm{Ci} / \mu \mathrm{g}\right)$. Immunoreactive bands were visualized by autoradiography and quantitated by scanning densitometry: $A$, calcineurin $(0.25 \mu \mathrm{g}) ; B$, calcineurin $(0.125 \mu \mathrm{g})$; $C$, synaptosol; $D$, TX-sol SPM fraction; $E$, microsomes; $F$, cytosol; $G$, SJs; $H$, SPMs; $I$, crude synaptic membrane/mitochondrial pellet; and $J$, forebrain homogenate. Subcellular fractions were electrophoresed at $40 \mu \mathrm{g} / \mathrm{lane}$. Each fraction was analyzed on four separate Western blots (other blots contained fractions at 50,25 , or $20 \mu \mathrm{g}$ of protein/lane). Each blot also contained purified calcineurin standards (0.5, $0.25,0.125$, and $0.0625 \mu \mathrm{g} / \mathrm{lane}$ ). Values under each lane indicate the average relative calcineurin content (micrograms of calcineurin per milligram of protein) in the different subcellular fractions; values for each fraction varied less than $10 \%$ from each other between Western blots.

substrate-phosphatase interactions (Sherry et al., 1978; Hoar et al., 1979; Cassel and Glaser, 1982).

The studies herein examined whether the endogenous PrP activity in SJ and SPM fractions resulted from the presence of one or more of the type-1 or type-2 protein phosphatases. Using ${ }^{32} \mathrm{P}$-phosphorylase $a$ as a substrate, PrP-1 and PrP-2A were found to be present in all synaptic fractions. Moreover, addition of homogeneous preparations of these phosphatases to ${ }^{32} \mathrm{P}$-SJ fractions revealed that PrP-1 and PrP-2A could completely dephosphorylate all phosphoproteins that are in vitro substrates for CaM-kinase II. The rates of dephosphorylation (in terms of percentage of release of ${ }^{32} \mathrm{P}$ ) for the 50 -, 60 -, and 140-kd proteins in SJs by PrP-1 and PrP-2A were $60 \%$ and $50 \%$, respectively, of that observed using phosphorylase $a$ as a substrate. When inhibitor -1 and/or inhibitor-2 were added to dephosphorylation reactions at concentrations sufficient to totally inhibit PrP. 1 , the endogenous phosphatase activities in SJ and SPM fractions were greatly inhibited. The inhibition observed in each synaptic fraction was consistent with the relative amounts of PrP-1 and PrP$2 \mathrm{~A}$ activities present in each, based on measurements using ${ }^{32} \mathrm{P}$. phosphorylase $a$ as a substrate.

Further experiments demonstrated that the specific activity of PrP. $2 \mathrm{~B}$ and PrP-2C was very low in SPM and SJ fractions and that these enzymes did not contribute significantly toward the dephosphorylation of SJ proteins (see "Results"). Taken together, these results show that the endogenous phosphatase activity in synaptic fractions is due primarily to PrP-1 with a small contribution by PrP-2A. Our findings indicated that, of the total phosphatase activity in SJs, approximately four-fifths of it was PrP-1 and one-fifth was PrP-2A, whereas the ratio for SPMs was 4:1. Whether or not PrP-1 preferentially regulates in vivo dephosphorylation processes at synaptic junctions remains to be answered.

The near-absence of immunoreactive staining, on the one hand, and low specific activity of PrP-2B (calcineurin) in SJ fractions, on the other, is surprising in light of immunohistochemical findings which demonstrated that calcineurin is concentrated at postsynaptic densities in situ (Wood et al., 1980). Our results indicate that the fractionation procedures used to isolate SJs removes most of the calcineurin that appears to be present in postsynaptic structures in situ. Western blot analyses performed herein demonstrated that calcineurin in rat brain is recovered primarily in cytosolic fractions. The highest concentration of calcineurin was observed in synaptosolenriched fractions which suggests that it may be an abundant component of presynaptic terminals. Alternatively, calcineurin is a major component of postsynaptic densities in situ and, due to its dissociation properties, redistributes into soluble extracts during tissue homogenization and subcellular fractionation. Our results indicate that purified calcineurin is virtually incapable of dephosphorylating the 240-, 207-, 170-, and 140-kd proteins in SJ fractions that are phosphorylated by endogenous CaM-kinase II, or the auto- phosphorylated subunits of this kinase. King et al. (1984) have shown that purified calcineurin displayed high catalytic efficiency in dephosphorylating purified G-substrate, DARPP. 32 and protein K.F.; however, synapsin I was a much poorer substrate for this phosphatase.

The endogenous PrP activity in SJs was clearly distinct from that of a number of commercially available acid and alkaline phosphatases in that the latter were virtually incapable of dephosphorylating nondenatured SJ phosphoproteins that are substrates for $\mathrm{CaM}$ kinase II.

These studies demonstrated PrP activity in cytosolic extracts from brain that was capable of dephosphorylating SJ phosphoproteins. Previous studies have demonstrated the presence of PrP activities in brain extracts and crude particulate fractions (Forn and Greengard, 1978; Yang et al., 1982; Foulkes et al., 1983). Our stúdies demonstrated that both cytosolic and synaptoplasmic fractions contain PrP activities, with the activity in the latter being greatest. This observation suggests that phosphatase activity is enriched in synaptosolic compartments of neurons compared to cytosolic fractions from brain tissue (i.e., neuronal plus non-neuronal cytosol). Approximately 35\% of the measured activity in cytosolic fractions displayed PrP-1 properties.

PrP-1 is highly enriched in synaptic particulate fractions. The ratio of PrP-1 to PrP-2A in the SJ and SPM fractions is much higher (10fold) than in soluble fractions. The specific association of PrP-1 with SPM and SJ fractions suggests that it may play a functional role in regulating the state of phosphorylation of nerve terminal proteins. It is tempting to speculate about this role within the scheme of neuronal transmission and the regulation thereof. The in vitro activity of the SJ-associated CaM-kinase II is modulated by autophosphorylation at low and possibly physiological CaM concentrations (15 to $50 \mathrm{nM}$ ) (Shields et al., 1984). We have demonstrated that the autophosphorylation of CaM-kinase II increases its affinity for CaM and, therefore, phosphorylated CaM-kinase II displays greater activity at low CaM concentrations than does its unphosphorylated counterpart. PrP-1 is preferentially enriched at synaptic junctions and dephosphorylates the autophosphorylated subunits of CaM-kinase II. Thus, the role of PrP-1 in dephosphorylating SJ proteins, especially CaM-kinase II, represents a logical modulatory mechanism to restore SJ phosphoproteins to their unphosphorylated states.

LeVine et al. (1985) have recently shown that the autophosphorylation of CaM-kinase II in cytoskeletal preparations from brain increases the affinity of the kinase for ${ }^{125} \mathrm{I}-\mathrm{CaM}$ when analyzed by the gel overlay method. However, the affinity of nondenatured cytoskeletal preparations for $\mathrm{CaM}$ at low $\mathrm{Ca}^{2+}$ concentrations $(0.5$ $\mu \mathrm{M}$ ) decreases following autophosphorylation.

Several mechanisms for regulating PrP-1 activity have been identified. One involves the phosphorylation of inhibitor-1 on a specific threonine residue by CAMP-dependent protein kinase. The phospho- 
form of inhibitor-1 is active as an inhibitor of PrP.1, whereas the dephosphoform is inactive (Huang and Glinsmann, 1976). In skeletal muscle the extent of phosphorylation of inhibitor- 1 is increased in response to the $\beta$-agonist epinephrine (Foulkers and Cohen, 1979). If, as predicted from immunochemical studies (Wood et al., 1980), PrP-2B (calcineurin) does function at postsynaptic densities in vivo, an additional element in the control of PrP-1 may be introduced. In liver and skeletal muscle, in vitro measuremerits of the dephosphorylation of phosphoinhibitor-1 indicate that PrP-2B constitutes the major phosphatase activity toward this phosphoprotein when assays are carried out in the presence of micromolar calcium ions (Ingebritsen et al., 1983c). Thus, steady-state levels of phosphorylation of inhibitor-1 and, consequently, the activity of PrP-1 at synaptic junctions may be controlled both by cAMP and by calcium ions (Ingebritsen and Cohen, 1983a). Elevation of CAMP would lead to inhibition of PrP-1, whereas elevated levels of free $\mathrm{Ca}^{2+}$ would have the opposite effect. A clear understanding of the possible roles of these regulatory mechanisms at synaptic junctions must await further studies to determine whether inhibitor- 1 is present in SJs and whether the state of phosphorylation of inhibitor- 1 "is responsive to cyclic AMP. DARPP-32, a dopamine-regulated phosphoprotein concentrated in the basal ganglia is also a potent inhibitor of PrP-1 (Hemmings et al., 1984). DARPP-32 shares many molecular properties with inhibitor-1. Both are active only in phosphorylated forms and are dephosphorylated by PrP-2B. It will be of interest to determine whether DARPP-32 is present in SJ fractions and whether addition of exogenous $\mathrm{PrP}-2 \mathrm{~B}$ to $\mathrm{SJ}$ fractions results in the dephosphorylation of DARPP-32 and/or phosphoinhibitor-1 or other SJ proteins in a calcium-dependent manner.

\section{References}

Antoniw. J. F and P. Cohen (1976) Separation of two phosphorylase kinase phosphatases from rabbit skeletal muscle. Eur. J. Biochem. 68: 45-54.

Banker, G., L. Churchill, and C. W. Cotman (1974) Proteins of the postsynaptic density. J. Ccll Biol. 63: 456465

Bennett, M. K., N. E. Erondu, and M. B. Kennedy (1983) Purification and characterization of a calmodulin-dependent protein kinase that is highly concentrated in brain. J. Biol. Chern. 258: 12735-12744

Cassel, D., and L. Glaser (1982) Resistance to phosphatase of thiophosphorylated epidermal growth factor receptor in A431 membranes. Proc. Natl. Acad. Sci. U. S. A. 79: 2231-2235.

Cohen, P. (1973) The subunit structure of rabbit-skeletal-muscle phosphorylase kinase, and the molecular basis of its activation reactions. Eur. $\mathrm{J}$ Biochem. 34: 1-14.

Cotman, C. W. and P. T. Kelly (1980) Macromolecular architecture of CNS synapses. In Cell Surface Reviews, C. Cotman, G. Nicolson, and G. Poste, eds., pp. 505-533, Elsevier-North Holland Publishing Co., Amsterdam.

De Camilli, P., S. Harris, W. Huttner, and P. Greengard (1983) Synapsin I (protein I), a nerve terminal-specific phosphoprotein. II. Its specific association with synaptic vesicles demonstrated by immunocytochemistry in agarose-embedded synaptosomes. J. Cell Biol. 96: 1355-1373.

Fischer, E. H., and E. G. Krebs (1958) The isolation and crystallization of rabbit skeletal muscle phosphorylase b. J. Biol. Chem. 231: 65-71.

Forn, J., and P. Greengard (1978) Depolarizing agents and cyclic nucleotides regulate the phosphorylation of specific neuronal proteins in rat cerebral slices. Proc. Natl. Acad. Sci. U. S. A. 75: 5195-5199.

Foulkes, J. G., and P. Cohen (1979) The hormonal control of glycogen metabolism. Phosphorylation of protein phosphatase inhibitor- 1 in vivo in response to adrenaline. Eur. J. Biochem. 97: 251-256.

Foulkes, J. G., and P. Cohen (1980) The regulation of glycogen metabolism. Purification and properties of protein phosphatase inhibitor-2 from rabbit skeletal muscle. Eur. J. Biochem. 105: 195-203

Foulkes, J. G., E. Erikson, and R. L. Erikson (1983) Separation of multiple phosphotyrosyl- and phosphoseryl-protein phosphatases from chicken brain. J. Biol. Chem. 258: 431-438.

Goldenring, J., B. Gonzalez, and R. DeLorenzo (1982) Isolation of brain $\mathrm{Ca}^{++}$-camodulin tubulin kinase containing calmodulin binding proteins Biochem. Biophys. Res. Commun. 108: 421-428.

Goldenring, J., J. McGuire, and R. DeLorenzo (1984) Identification of the major postsynaptic density protein as homologous with the major calmod ulin binding subunit of a calmodulin dependent protein kinase. J. Neurochem. 42: 1077-1084

Grab, D. J., R. K. Carlin, and P. Siekevitz (1981) Function of calmodulin in postsynaptic densities. II. Presence of a calmodulin-activatable protein kinase activity. J. Cell Biol. 89: 440-448.

Groswald, D. E., and P. Kelly (1984) Evidence that a cerebellum-enriched, synaptic junction glycoprotein is related to fodrin and resists extraction with Triton in a $\mathrm{Ca}^{++}$-dependent manner. J. Neurochem. 42: 534-546.

Groswald, D. E., P. R. Montgomery, and P. Kelly (1983) Synaptic junctions isolated from cerebellum and forebrain: Comparisons of morphological and molecular properties. Brain Res. 278: 63-80.

Hemmings, H. C., P. Greengard, H. Y. Lim Tung, and P. Cohen (1984) DARPP-32, a dopamine-regulated neuronal phosphoprotein, is a potent inhibitor of protein phosphatase-1. Nature 310:503-505.

Hoar, P. E., W. Kerrick, and P. Cassidy (1979) Chicken gizzard: Relation between calcium-activated phosphorylation and contraction. Science 204 503-506

Huang, F. L., and W. H. Glinsmann (1976) Separation and characterization of two phosphorylase phosphatase inhibitors from rabbit skeletal muscle. J. Biochem. 70: 419-426.

Ingebritsen, T. S., and P. Cohen (1983a) Protein phosphatases: Properties and role in cellular regulation. Science 221: 331-338.

Ingebritsen, T. S., and P. Cohen (1983b) The protein phosphatases involved in cellular regulation I. Classification and substrate specificities. Eur. J. Biochem. 132: 255-261.

Ingebritsen, T. S., J. Blair, P. Guy, L. Witters, and D. G. Hardie (1983a) The protein phosphatases involved in cellular regulation. III. Fatty acid synthesis, cholesterol synthesis and glycolysis/giuconeogenesis. Eur. J. Biochem. 132: $275-281$

Ingebritsen, T. S., J. G. Foulkes, and P. Cohen (1983b) The protein phosphatases involved in cellular regulation. II. Glycogen metabolism. Eur. J. Biochem. 132: 263-274

Ingebritsen, T. S., A. A. Stewart, and P. Cohen (1983c) The protein phosphatases involved in cellular regulation. VI. Measurement of type- 1 and type-2 protein phosphatases in extracts of mammalian tissues; an assessment of their physiological roles. Eur. J. Biochem. 132: 297-307.

Kelly, P. T., and C. W. Cotman (1978) Characterization of tubulin and actin and identification of a distinct PSD polypeptide. J. Cell Riol. 79: 173-183.

Kelly, P. T., and P. R. Montgomery (1982) Subcellular localization of the 52,000 molecular weight major postsynaptic density protein. Brain Res. 233: 265286

Kelly, P. T., M. Largen, and C. W. Cotman (1979) Cyclic AMP-stimulated protein kinases at brain synaptic junctions. J. Biol. Chem. 254: 15641575.

Kelly, P. T., T. L. McGuinness, and P. Greengard (1983) Calcium/calmodulindependent phosphorylation in synaptic junctions. Soc. Neurosci. Abstr. 9: 1030

Kelly, P. T., T. L. McGuinness, and P. Greengard (1984) Evidence that the major postsynaptic density protein is a component of a Ca ${ }^{++}$calmodulin dependent protein kinase. Proc. Natl. Acad. Sci. U. S. A. 81: 945-949.

Kelly, P. T., R. Yip, S. M. Shields, and M. Hay (1985) Calmodulin-dependent protein phosphorylation in synaptic junctions. I. Neurochem. 45: 16201634

Kennedy, M. B., and P. Greengard (1981) Two calcium/calmodulin-dependent protein kinases, which are highly concentrated in brain, phosphorylate protein I at distinct sites. Proc. Natl. Acad. Sci. U. S. A. 78: 1293-1297.

Kennedy, M. B., T. L. McGuinness, and P. Greengard (1983a) A calcium/ calmodulin-dependent protein kinase from mammalian brain that phosphorylates synapsin I: Partial purification and characterization. J. Neurosci. 3: 818-826

Kennedy, M. B., M. K. Bennett, and N. E. Erondu (1983b) Biochemical and immunochemical evidence that the major postsynaptic density protein is a subunit of a calmodulin-dependent protein kinase. Proc. Natl. Acad. Sci. U. S. A. $80: 7357-7361$

King, M. M., C. Huang, P. Boon Chock, A. Nairn, H. Hemmings, K. -F. Jesse Chan, and P. Greengard (1984) Mammalian brain phosphoproteins as substrates for calcineurin. J. Biol. Chem. 259: 8080-8083.

Klee, C.B., T. Crouch, and M. Krinks (1979) Calcineurin: A calcium- and calmodulin-binding protein of the nervous system. Proc. Natl. Acad. Sci. U. S. A. 76: 6270-6273

Krueger, B. K., J. Forn, and P. Greengard (1977) Depolarization-induced phosphorylation of specific proteins, mediated by calcium ion influx, in rat brain synaptosomes. J. Biol. Chem. 252: 2764-2773

Lai, Y., T. L. McGuinness, and P. Greengard (1983) Purification and char acterization of brain $\mathrm{Ca}^{2+} /$ calmodulin-dependent protein kinase $\|$ that phosphorylates synapsin I. Soc. Neurosci. Abstr. 9: 1029.

LeVine, H., II, N. Sahyoun, and P. Cuatrecasas (1985) Calmodulin binding to the cytoskeletal neuronal calmodulin-dependent protein kinase is regulated by autophosphorylation. Proc. Natl. Acad. Sci. U. S. A. 82: 287-291. 
Lim Tung, H. Y., T. S. Nesink, B. A. Hemmings, S. Shenolikar, and P Cohen (1984) The catalytic subunits of protein phosphatase-1 and protein phos phatase-2A are distinct gene products. Eur. J. Biochem. 138: 635-641.

McGuinness, T. L., P. T. Kelly, C. C. Ouimet, and P. Greengard (1983) Studies on the subcellular and regional distribution of calmodulin-dependent protein kinase II in rat brain. Soc. Neurosci. Abstr. 9: 1029.

Nirnmo, G. A., and P. Cohen (1978) The regulation of glycogen metabolism. Purification and characterization of protein phosphatase inhibitor-1 from rabbit skeletal muscle. Eur. J. Biochem. 87: 341-351.

Paltrey, H. C., J. E. Rothlein, and P. Greengard (1983) Calmodulin-dependent protein kinase and associated substrates in Torpedo electric organ. J. Biol. Chem. 258: 9496-9503.

Pato, M. D., R. S. Adelstein, D. Crouch, B. Safer, T. S. Ingebritsen, and P. Cohen (1983) The protein phosphatases involved in cellular regulation. IV. Classification of two homogenous myosin light chain phosphatases from smooth muscle as protein phosphatase- $2 \mathrm{~A}_{1}$ and $2 \mathrm{C}$, and a homogenous protein phosphatase from reticulocytes active on protein synthesis initiation factor elF-2 as protein phosphatase-2A 2 . Eur. J. Biochem. 132: 283-287.

Schulman, H. (1984) Phosphorylation of microtubule-associated proteins by a Ca ${ }^{++} /$calmodulin-dependent protein kinase. J. Cell Biol. 99: 11-19.

Sherry, J. M. F., A. Gorecka, M. D. Aksoy, R. Dabrowska, and D. J. Hartshorne (1978) Roles of calcium and phosphorylation in the regulation of the activity of gizzard myosin. Biochemistry 17: 4411-4418.

Shields, S., P. Vernon, and P. I. Kelly (1984) Modulation of calmodulin-kinase II activity in brain synaptic junctions by autophosphorylation. J. Neurochem. 43: $1599-1609$.

Stewart, A. A., T. S. Ingebritsen, A. Manalan, C. B. Klee, and P. Cohen (1982) Discovery of a $\mathrm{Ca}^{++}$- and calmodulin-dependent protein phospha- tase. Probable identity with calcineurin (CaM-BP $\left.{ }_{80}\right)$. FEBS Lett. 137: 8084

Stewart, A. A., T. S. Ingebritsen, and P. Cohen (1983) The protein phospha tases involved in cellular recognition. $V$. Purification and properties of a $\mathrm{Ca}^{++} /$calmodulin-dependent protein phosphatase (2B) from rabbit skeletal muscle. Eur. J. Biochem. 132: 289-295

Tonks, N. K., and P. Cohen (1983) Calcineurin is a calcium ion-dependent, calmodulin-stimulated protein phosphatase. Biochem. Biophys. Acta 747: 191-193

Ueda, I., P. Greengard, K. Berzıns, R. S. Cohen, F. Blomberg, D. J. Grab, and P. Siekevitz (1979) Subcellular distribution in cerebral cortex of two proteins phosphorylated by cAMP dependent protein kinase. J. Cell Biol. 83: $308-319$.

Wood, J. G., R. W. Wallace, J. N. Whitaker, and W. Y. Cheung (1980) Immuno-cytochemical localization of calmodulin and a heat-labile calmod ulin-binding protein (CaM-BP80) in basal ganglia of mouse brain. J. Cell Biol. 84: 66-76.

Yamauchi, T., and H. Fujisawa (1982) Phosphorylation of microtubule-associated protein 2 by calmodulin-dependent protein kinase (kinase II) which occurs only in the brain tissues. Biochem. Biophys. Res. Commun. 109. 975-981.

Yamauchi, T., and H. Fujisawa (1983) Purification and characterization of the brain calmodulin-dependent protein kinase (kinase II), which is involved in the activation of tryptophan 5-monooxygenase. Eur. J. Biochern. 132: 1521.

Yang, S., E. A. Tallant, and W. Y. Cheung (1982) Calcineurin is a calmodulin dependent protein phosphatase. Biochem. Biophys. Res. Commun. 106. $1419-1425$. 